\title{
Modeling of probability in obtaining intensity-duration-frequency relationships of rainfall occurrence for Pelotas, RS, Brazil
}

\author{
Viviane R. Dorneles ${ }^{1}$, Rita de C. F. Damé2 , Claudia F. A. Teixeira-Gandra ${ }^{2}$, \\ Patrick M. Veber ${ }^{3}$, Gustavo B. Klumb ${ }^{4} \&$ Mario A. A. Ramirez ${ }^{5}$ \\ ${ }^{1}$ Universidade Federal de Pelotas/Centro de Desenvolvimento Tecnológico/Programa de Pós-Graduação em Recursos Hídricos, Pelotas, RS, Brasil. E-mail: \\ vivianerdorneles@gmail.com (Corresponding author) - ORCID: 0000-0001-6095-5042 \\ ${ }^{2}$ Universidade Federal de Pelotas/Centro de Engenharias, Pelotas, RS, Brasil. E-mail: ritah2o@hotmail.com - ORCID: 0000-0001-9962-7855; cfteixei@gmail.com \\ - ORCID: 0000-0002-7482-0189 \\ ${ }^{3}$ Universidade Federal de Pelotas/Faculdade de Agronomia Eliseu Maciel/Programa de Pós-Graduação em Manejo e Conservação do Solo e da Água, Pelotas, RS, \\ Brasil. E-mail: patrick.veber@hotmail.com - ORCID: 0000-0001-7184-9237 \\ ${ }^{4}$ Solinftec. Nova Mutum, MT, Brasil. E-mail: gustavo19klumb@hotmail.com - ORCID: 0000-0002-6345-0936 \\ ${ }^{5}$ Fundación TecniAgro. Orito, Putumayo, Colombia. E-mail: maarcosr@unal.edu.co - ORCID: 0000-0002-1213-3332
}

\begin{abstract}
Based on historical series, for each locality, equations can characterize the relationship between intensity, duration and frequency of rainfall occurrence. The objective of this study was to present two equations that can describe the occurrence of intense rainfall in Pelotas, RS state, over the period 1982-2015. The two equations were denominated conventional and hybrid, depending on the probabilistic model used. Following the conventional methodology, the parameters of Normal, Log-Normal, Gumbel and Gamma probability distributions were adjusted by the maximum likelihood method for return periods of $2,5,10,20,25,50$ and 100 years. The maximum intensity values for the hybrid equation were obtained using the empirical model of Weibull, considering return periods of 2, 5, 10,20 and 25 years. On the other hand, the same theoretical distributions used in the conventional equation were applied to return periods of 50 and 100 years. The Kolmogorov-Smirnov test was used to select the best fitting distribution for the data. In order to verify the information acquired through the Weibull empirical model in comparison to the theoretical distributions, the t-test was applied to the angular coefficients. Significant differences were not verified between the values of maximum rainfall intensities obtained using the two methodologies, for the pre-established durations and return periods. Thus, considering the maximum rainfall intensities values (durations of 5-1440 min) and return periods of 2-100 years in the municipality of Pelotas, RS, Brazil, both the hybrid and the conventional intense rainfall equations can be used.
\end{abstract}

Key words: rainfall records, intense rainfalls, maximum rainfall intensities

\section{Modelagem da probabilidade das relações intensidade-duração-frequência de ocorrência da precipitação pluvial para Pelotas, RS}

RESUMO: Com base em séries históricas, para cada localidade, equações podem caracterizar a relação entre a intensidade, duração e frequência de ocorrência de precipitação pluvial. Objetivou-se apresentar duas equações para a localidade de Pelotas, RS, no período de 1982-2015, uma denominada convencional e outra híbrida, dependendo do modelo probabilístico utilizado. Na metodologia convencional foram ajustados os parâmetros das distribuições de probabilidade Normal, Log-Normal, Gumbel e Gama, pelo método da máxima verossimilhança, para os períodos de retorno de 2, 5, 10,20, 25, 50 e 100 anos. Para a equação híbrida, os valores de intensidade máxima foram obtidos utilizando o modelo empírico de Weibull, nos períodos de retorno de 2, 5, 10,20, 25 anos. Por outro lado, as mesmas distribuições teóricas utilizadas na equação convencional foram aplicadas para os períodos de retorno de 50 e 100 anos. A seleção da distribuição que melhor se ajustou aos dados foi realizada pelo teste Kolmogorov-Smirnov. Para verificar o ganho de informação em utilizar o modelo empírico de Weibull, comparativamente às distribuições teóricas, utilizou-se o teste $t$ para o coeficiente angular. Com base nos resultados não foram verificadas diferenças significativas entre os valores de intensidade máxima obtidos por ambas metodologias, nas durações e períodos de retorno préestabelecidos. Assim conclui-se que para a obtenção dos valores de intensidade máxima, nas durações de 5 a 1440 min, nos períodos de retorno de 2 a 100 anos, para o município de Pelotas, RS, pode-se utilizar tanto a equação de chuvas intensas denominada híbrida como a convencional.

Palavras-chave: registros pluviográficos, chuvas intensas, intensidades máximas de chuva 


\section{INTRODUCTION}

The intensity-duration-frequency (IDF) relationship of rainfall occurrence can be represented by mathematical models generated from historical data series, such as rainfall records, relative to the place of interest (Silva et al., 2002; Souza et al., 2012).

The conventional methodology for obtaining intensityduration-frequency relationships has been widely reported in the literature (Goulart et al., 1992; Garcia et al., 2011; Damé et al., 2016). Nevertheless, some questions still need to be answered: (i) Why theoretical models of probability should be used to obtain values of maximum intensity for return periods shorter than the length of the sampled period? (ii) What is the influence of the objective function on the intensity-durationfrequency relationships coefficients obtained through the numerical optimization algorithm? (iii) Can someone prove that there are no significant differences between the values of historical maximum intensity and those obtained through the traditional methodology?

These questions justify the hypothesis that the period and size of the data series, as well as the values of maximum rainfall intensity over short periods of time, should be considered in the analysis of intense rains.

Despite the apparent availability of intensity-durationfrequency relationships, it is important to note that the limits of the equations are mostly unknown: these limitations may interest in particular the type of series used, the annual or partial rainfall duration (Sansigolo, 2008), the extension and representativeness of the series, the duration and the return period.

In this view, the present work aims at obtaining intensityduration-frequency relationships from available pluviographic records (1982-2015) for the locality of Pelotas, Rio Grande do Sul state, by considering both conventional and hybrid methodologies and using both empirical and theoretical probability models.

\section{MAterial AND Methods}

The city of Pelotas is located in the state of Rio Grande do Sul, Brazil ( $\left.31^{\circ} 46^{\prime} 34^{\prime \prime} \mathrm{S}, 52^{\circ} 21^{\prime} 34^{\prime \prime} \mathrm{W}\right)$, at an average altitude of $13.2 \mathrm{~m}$. According to the Köppen climate classification, the city is located within a subtropical and humid region, which does not experience drought and has an average total annual rainfall of $1366.9 \mathrm{~mm}$.

The data used in this study were obtained from the Agroclimatological Station maintained by the Empresa Brasileira de Pesquisa Agropecuária (EMBRAPA) and the Universidade Federal de Pelotas (UFPEL), and comprise 34 years of pluviographic records (1982-2015).

The hyetographs, which include all rainy days, were used to calculate the maximum annual intensities $\left(\mathrm{mm} \mathrm{h}^{-1}\right)$ for pre-established durations of $5,10,15,20,30,60,120,360,720$ and $1440 \mathrm{~min}$.

The stationarity and independence of the maximum intensities obtained for different durations were verified using the non-parametric Mann-Kendall test and the sample autocorrelation function (Kendall \& Stuart, 1967; Blain \& Camargo, 2012; Blain \& Meschiatti, 2014), respectively.
An empirical frequency analysis was applied through the Weibull method to the maximum annual intensities associated with return periods (RP) of 2, 5, 10, 20, and 25 years; on the other hand, for return periods of 50 and 100 years, the probability distributions (Normal, Log-Normal, Gumbel and Gamma) were adjusted by the maximum likelihood method, composing hybrid series.

These types of distributions have been widely applied in previous studies (e.g., Silva et al., 2002; Sansigolo, 2008; Back et al., 2011; Souza et al., 2012; Mello \& Viola, 2013; Fechine Sobrinho et al., 2014), while the maximum likelihood method has been already used in Ramos \& Moala (2014) and Kruel et al. (2015).

The conventional series were obtained from the same probability distributions applied to the hybrid series, but considering return periods of $2,5,10,20,25,50$, and 100 years.

The probability distributions for the hybrid and conventional series were selected through the Kolmogorov-Smirnov test (0.05) (as in Ferreira et al., 2005; Soccol et al., 2010; Souza et al., 2013). The adjustment of the probability models and the KS test were performed through $\mathrm{R}$ software routines ( $\mathrm{R}$ Development Core Team, 2011).

To obtain the parameters of the intensity-durationfrequency equations, we minimized five objective functions (OF) (Eqs. 2 to 6) were minimized through the Microsoft Excel 'Solver' tool, which uses a non-linear optimization code called 'Generalized Reduced Gradient' (Martínez et al., 2012). The selected objective function was the one having the lowest Root Mean Square Error (RMSE).

The intensity-duration-frequency relations are presented in Eq. 1 (Borga et al., 2005; Silva et al., 2006):

$$
I=\frac{K R P^{a}}{(t+b)^{c}}
$$

where:

I - maximum average rainfall intensity, $\mathrm{mm} \mathrm{h}^{-1}$;

RP - return period, years;

$\mathrm{t}$ - rain duration, min; and,

$\mathrm{K}, \mathrm{a}, \mathrm{b}, \mathrm{c}$ - adjustment parameters of the equation.

OF 1 (Damé, 2001):

$$
Y=\sum_{i=1}^{n}\left[\left(\frac{X_{o b s}}{X_{e q}}\right)-1\right]^{2}
$$

$\mathrm{OF}_{2}$ : Root Mean Square Error:

$$
\mathrm{RMSE}=\sqrt{\frac{\sum_{\mathrm{i}=1}^{\mathrm{n}}\left(\mathrm{X}_{\mathrm{obs}}-\mathrm{X}_{\mathrm{eq}}\right)^{2}}{\mathrm{n}}}
$$

$\mathrm{OF}_{3}$ : Correlation coefficient:

$$
\mathrm{C}=\frac{\sum_{\mathrm{i}=1}^{\mathrm{n}}\left(\mathrm{X}_{\mathrm{obs}}-\overline{\mathrm{X}}_{\mathrm{obs}}\right)-\left(\mathrm{X}_{\mathrm{eq}}-\overline{\mathrm{X}}_{\mathrm{eq}}\right)}{\sum_{\mathrm{i}=1}^{\mathrm{n}}\left(\mathrm{X}_{\mathrm{obs}}-\overline{\mathrm{X}}_{\mathrm{obs}}\right)^{2}}
$$


$\mathrm{OF}_{4}$ : Normalized RMSE:

$$
\mathrm{NRMSE}=\frac{\mathrm{RMSE}}{\overline{\mathrm{X}}_{\mathrm{obs}}}
$$

$\mathrm{OF}_{5}$ : Nash-Sutcliffe efficiency coefficient:

$$
E=1-\frac{\sum_{i=1}^{n}\left(X_{o b s}-X_{e q}\right)^{2}}{\sum_{i=1}^{n}\left(X_{o b s}-\bar{X}_{o b s}\right)^{2}}
$$

where:

$\mathrm{X}_{\mathrm{obs}}$ - observed values of maximum rainfall intensity, $\mathrm{mm} \mathrm{h}^{-1}$;

$X_{e q}$ - estimated values of maximum rainfall intensity, $\mathrm{mm} \mathrm{h} \mathrm{h}^{-1}$, obtained from the intensity-duration-frequency relationships determined from each $\mathrm{OF}$;

$\mathrm{X}_{\mathrm{obs}}$ and $\mathrm{X}_{\mathrm{eq}}$ - arithmetic means of the observed and estimated series, respectively; and,

$\mathrm{n} \quad$ - total number of elements in the series.

After selecting the parameters and obtaining the hybrid and conventional intensity-duration-frequency, the values of maximum rainfall intensity $\left(\mathrm{mm} \mathrm{h}^{-1}\right)$ of the two intensityduration-frequency were compared between each other; the intensity-duration-frequency were then directly applied to the durations of interest through the Student's t-test.

For this test, the null hypothesis $\left(\mathrm{H}_{0}\right)$ for the angular coefficient $\beta_{1}$ was that $H_{0}: \beta_{1}=0$. In other words, there was no evidence of significant differences between the values of maximum intensities $\left(\mathrm{mm} \mathrm{h}^{-1}\right)$ obtained from the hybrid and conventional intensity-duration-frequency relationships.

\section{Results AND Discussion}

Table 1 shows the Mann-Kendall statistics ( $Z$ ) and the sample autocorrelation coefficients $\left(r_{1}\right)$ of the maximum rainfall intensities $\left(\mathrm{mm} \mathrm{h}^{-1}\right)$ for all durations.

According to Table 1, the values of maximum rainfall intensity for the pre-established durations were stationary, since the $Z$ values of the Mann-Kendall statistics were lower
Table 1. Mann-Kendall statistics ( $Z$ ) and sample autocorrelation coefficient $\left(r_{1}\right)$ of the maximum rainfall intensities $\left(\mathrm{mm} \mathrm{h}^{-1}\right)$ for durations of $5,10,15,20,30,60,120,360,720$ and 1440 min (years 1982-2015)

\begin{tabular}{|ccc|}
\hline $\begin{array}{c}\text { Rainfall duration } \\
(\mathbf{m i n})\end{array}$ & $\mathbf{Z}$ & $\mathbf{r}_{\mathbf{1}}$ \\
\hline 5 & -0.790 & 0.196 \\
10 & -0.928 & 0.124 \\
15 & -0.987 & 0.121 \\
20 & -0.991 & 0.120 \\
30 & -0.997 & 0.099 \\
60 & -1.000 & 0.087 \\
120 & -0.999 & 0.079 \\
360 & -0.999 & 0.065 \\
720 & -0.998 & 0.046 \\
1440 & -0.993 & 0.037 \\
\hline $\mathrm{Z}_{\text {critical }}=1.96 ; \mathrm{r}_{1}=(-0.366 ; 0.306) ; \mathrm{p} \leq 0.05$ & \\
\hline
\end{tabular}

than the critical values at $\mathrm{p} \leq 0.05$ (Pinheiro et al., 2013; Silva \& Streck, 2014).

Moreover, the results showed independence of the data, since the sample correlation coefficients $\left(r_{1}\right)$ for all durations were comprised within the confidence interval of 0.95 (Teixeira et al., 2011).

The Normal, Gumbel, Log-Normal and Gamma probability distributions were calculated through maximum likelihood estimation (MLE) for the series of maximum rainfall intensity $\left(\mathrm{mm} \mathrm{h}^{-1}\right)$ and rainfall durations of 5, 10, 15, 20, 30, 60, 120, 360, 720 and $1440 \mathrm{~min}$ (Table 2).

The parameters $\mu$ e $\sigma$, average and standard deviation, respectively, of the Normal distribution (Table 2) bring foward a decreasing behavior with increasing durations, in which the highest values are found in the shortest durations. This behavior is also observed for the parameters $\gamma$ (Gumbel distribution location parameter), $\mu_{\mathrm{LOG}}$ (Log-Normal distribution logarithmic data parameter) and $\beta$ (Gamma distribution scale parameter). This may be related to the characteristic of the historical series for analysis of intense rains in which high values of maximum intensities are associated to the small durations.

Table 3 presents the calculated values of KolmogorovSmirnov test (D) for the Normal, Gumbel, Log-Normal and Gamma probability distributions, obtained through maximum likelihood estimation (MLE) for the series of maximum rainfall intensity $\left(\mathrm{mm} \mathrm{h}^{-1}\right)$ and the analyzed durations.

Table 2. Normal, Gumbel, Log-Normal and Gamma probability distributions, estimated through maximum likelihood estimation

\begin{tabular}{|c|c|c|c|c|c|c|c|c|}
\hline \multirow{4}{*}{$\begin{array}{l}\text { Rainfall duration } \\
\text { (min) }\end{array}$} & \multicolumn{8}{|c|}{ Probability distributions } \\
\hline & \multicolumn{2}{|c|}{ Normal } & \multicolumn{2}{|c|}{ Gumbel } & \multicolumn{2}{|c|}{ Log-Normal } & \multicolumn{2}{|c|}{ Gamma } \\
\hline & \multicolumn{8}{|c|}{ Parameters } \\
\hline & $\boldsymbol{\mu}$ & $\sigma$ & $\gamma$ & $\lambda$ & $\overline{\mu_{\text {LOG }}}$ & $\sigma_{\mathrm{LOG}}$ & $\bar{\beta}$ & $v$ \\
\hline 5 & 111.64 & 21.64 & 85.74 & 0.040 & 4.69 & 0.225 & 22.80 & 4.90 \\
\hline 10 & 99.79 & 22.43 & 79.07 & 0.058 & 4.58 & 0.245 & 18.36 & 5.43 \\
\hline 15 & 83.67 & 22.15 & 73.23 & 0.056 & 4.39 & 0.265 & 14.90 & 5.61 \\
\hline 20 & 76.53 & 21.27 & 66.51 & 0.056 & 4.29 & 0.281 & 13.98 & 5.71 \\
\hline 30 & 61.12 & 17.10 & 53.16 & 0.071 & 4.07 & 0.281 & 13.37 & 4.57 \\
\hline 60 & 40.44 & 13.90 & 33.96 & 0.089 & 3.64 & 0.349 & 8.79 & 4.60 \\
\hline 120 & 25.93 & 10.46 & 21.17 & 0.125 & 3.18 & 0.399 & 6.65 & 3.90 \\
\hline 360 & 10.73 & 4.09 & 8.87 & 0.318 & 2.30 & 0.376 & 7.46 & 1.44 \\
\hline 720 & 6.26 & 2.61 & 5.17 & 0.592 & 1.76 & 0.369 & 7.21 & 0.87 \\
\hline 1440 & 2.35 & 1.74 & 1.53 & 0.693 & 0.32 & 1.321 & 1.07 & 2.19 \\
\hline
\end{tabular}
(MLE) for the series of maximum rainfall intensity $\left(\mathrm{mm} \mathrm{h}^{-1}\right)$ and durations of 5, 10, 15, 20, 30, 60, 120, 360, 720 and 1440 min

$\mu$ and $\sigma-$ Mean and standard deviation of the sample; $\gamma$ and $\lambda$ - Location and scale parameters; $\mu_{\mathrm{LOG}}$ and $\sigma_{\mathrm{LOG}}-$ Mean and standard deviation of the logarithmic data; $\beta$ and $\nu$ - Scale and shape parameters 
Table 3. Calculated values of Kolmogorov-Smirnov test (D) for the Normal, Gumbel, Log-Normal and Gamma probability distributions, obtained through maximum likelihood estimation (MLE) for the series of maximum rainfall intensity $\left(\mathrm{mm} \mathrm{h}^{-1}\right)$ and rainfall durations in the municipality of Pelotas, RS state, Brazil

\begin{tabular}{|ccccc|}
\hline \multirow{2}{*}{$\begin{array}{c}\text { Rainfall } \\
\text { duration }\end{array}$} & \multicolumn{4}{c}{ Distributions } \\
\cline { 2 - 5 }$(\boldsymbol{m i n})$ & Normal & Gamma & Gumbel & Log-Normal \\
\cline { 2 - 5 } 5 & 0.3649 & 0.3794 & 0.3590 & 0.3831 \\
10 & 0.2174 & 0.2149 & 0.1911 & 0.2010 \\
15 & 0.1091 & 0.1107 & 0.1062 & 0.1095 \\
20 & 0.1182 & 0.0889 & 0.0857 & 0.0961 \\
30 & 0.1345 & 0.1031 & 0.0740 & 0.0855 \\
60 & 0.1252 & 0.1191 & 0.1184 & 0.1193 \\
120 & 0.1098 & 0.0911 & 0.1010 & 0.1034 \\
360 & 0.1567 & 0.1098 & 0.0846 & 0.0849 \\
720 & 0.1928 & 0.1848 & 0.1792 & 0.1794 \\
1440 & 0.1903 & 0.1802 & 0.1302 & 0.2052 \\
\hline KS $=0.2274 ; \mathrm{p} \leq 0.05 ;$ D - Calculated KS statistics for 34 years of data \\
\hline
\end{tabular}

The Gumbel probability distribution had the lowest values for most durations, among those calculated through the KS test $(\mathrm{p} \leq 0.05)$. The Gamma distribution presented a lower KS statistic value only for a duration of $120 \mathrm{~min}$.

Since a continuous random variable can be represented by more than one probabilistic model, it is important to choose the appropriate data series distribution for the studied locality, in order to minimize the error linked to the estimation of maximum rainfall intensity values for long return periods (Sansigolo et al., 2008; Back et al., 2011; Beskow et al., 2015).

Table 3 shows how, for a duration of $5 \mathrm{~min}$, none of the tested distributions were adequately adjusted to the series: the statistic values obtained from the KS test were higher than those of the critical statistics $(0.2274 ; \mathrm{p} \leq 0.05)$, rejecting $\mathrm{H}_{0}$ and indicating that the observed data were not distributed similarly to the tested distributions.

The inadequacy of the data in respect to the probability distributions can be explained by the existence of repetitive maximum rainfall intensity values (e.g., $120 \mathrm{~mm} \mathrm{~h}^{-1}$ ). These repeated values were obtained by the interpretation of the hyetographs, and the maximum rainfall intensities were calculated to obtain series of pre-established duration.

In applying the probability distributions to the series with repeated values, the same values were actually considered in different positions; hence, different values of occurrence probability were assigned to the same value of maximum rainfall intensity $\left(120 \mathrm{~mm} \mathrm{~h}^{-1}\right)$, causing an inadequate adjustment of the series distributions.

The probability distribution of Gumbel was selected and obtained the maximum rainfall intensity values for durations from 5 to $1440 \mathrm{~min}$, and for return periods from 2 to 100 years (Table 4). These values were subsequently employed to obtain the conventional and hybrid intensity-duration-frequency parameters.

Table 4 shows that for the shortest duration analyzed ( $5 \mathrm{~min}$ ), the maximum rainfall intensities were higher than those observed for longer durations. The high values of maximum rainfall intensities for short durations $(5,10,15,20$ and $30 \mathrm{~min})$ were expected considering the characteristics of intense rains.

In the case of hybrid intensity-duration-frequency relationship, the maximum rainfall intensities for each duration were estimated empirically; in fact, as mentioned before, the historical series included 34 years of data and it was possible to use historical values of maximum rainfall intensity for return period of up to 25 years. For longer return period (50 and 100 years), the maximum rainfall intensity values obtained from the Gumbel distribution were considered.

Table 5 shows the $\mathrm{K}, \mathrm{a}, \mathrm{b}$ and c coefficients of the conventional and hybrid intensity-duration-frequency equations, obtained by minimizing the objective functions, and the results of the RMSE.

For the conventional intensity-duration-frequency equation, the lowest RMSE value was obtained by applying

Table 4. Maximum rainfall intensity values $\left(\mathrm{mm} \mathrm{h}^{-1}\right)$ for conventional and hybrid intensity-duration-frequency relationships in the municipality of Pelotas, RS state, Brazil

\begin{tabular}{|c|c|c|c|c|c|c|c|}
\hline \multirow{2}{*}{$\begin{array}{l}\text { Rainfall duration } \\
\text { (min) }\end{array}$} & \multicolumn{7}{|c|}{ Return period (years) } \\
\hline & 2 & 5 & 10 & 20 & 25 & 50 & 100 \\
\hline & \multicolumn{7}{|c|}{ Conventional series } \\
\hline 5 & 109.26 & 137.42 & 156.07 & 173.95 & 179.63 & 197.10 & 214.45 \\
\hline 10 & 96.39 & 121.21 & 137.64 & 153.40 & 158.39 & 173.79 & 189.08 \\
\hline 15 & 79.81 & 100.15 & 113.62 & 126.55 & 130.65 & 143.27 & 155.81 \\
\hline 20 & 73.01 & 93.10 & 106.41 & 119.17 & 123.22 & 135.69 & 148.07 \\
\hline 30 & 58.35 & 74.43 & 85.07 & 95.27 & 98.51 & 108.49 & 118.39 \\
\hline 60 & 38.10 & 50.88 & 59.34 & 67.46 & 70.04 & 77.97 & 85.84 \\
\hline 120 & 24.64 & 33.80 & 39.36 & 44.38 & 45.91 & 50.49 & 54.84 \\
\hline 360 & 10.03 & 13.59 & 15.96 & 18.22 & 18.94 & 21.16 & 23.36 \\
\hline 720 & 5.79 & 7.70 & 8.97 & 10.18 & 10.57 & 12.76 & 12.94 \\
\hline 1440 & 2.35 & 3.80 & 4.55 & 5.17 & 5.35 & 5.93 & 6.40 \\
\hline \multicolumn{8}{|c|}{ Hybrid series } \\
\hline 5 & 120.00 & 120.00 & 120.51 & 132.17 & 144.51 & 197.10 & 214.45 \\
\hline 10 & 109.20 & 120.00 & 120.00 & 122.44 & 124.93 & 173.79 & 189.08 \\
\hline 15 & 80.00 & 104.00 & 120.00 & 120.00 & 120.00 & 143.27 & 155.81 \\
\hline 20 & 75.00 & 94.80 & 107.57 & 120.00 & 120.00 & 135.69 & 148.07 \\
\hline 30 & 56.60 & 78.60 & 89.83 & 94.29 & 94.86 & 108.49 & 118.39 \\
\hline 60 & 36.80 & 53.33 & 58.45 & 67.51 & 70.01 & 77.97 & 85.84 \\
\hline 120 & 24.35 & 35.13 & 42.18 & 44.45 & 47.62 & 50.49 & 54.84 \\
\hline 360 & 9.81 & 14.50 & 17.31 & 18.68 & 19.65 & 21.16 & 23.36 \\
\hline 720 & 5.08 & 8.80 & 10.60 & 11.91 & 12.72 & 12.76 & 12.94 \\
\hline 1440 & 2.50 & 3.80 & 4.70 & 5.63 & 5.89 & 5.93 & 6.40 \\
\hline
\end{tabular}


Table 5. K, a, b and c coefficients of the conventional and hybrid intensity-duration-frequency equations, obtained from the objective functions (OF) for the maximum rainfall intensities data series

\begin{tabular}{|c|c|c|c|c|c|}
\hline \multirow{2}{*}{ Coefficients } & \multicolumn{5}{|c|}{ Objective function (OF) } \\
\hline & $\overline{O F_{1}}$ & $\mathrm{OF}_{2}$ & $\mathrm{OF}_{3}$ & $\mathrm{OF}_{4}$ & $\mathrm{OF}_{5}$ \\
\hline & \multicolumn{5}{|c|}{ Conventional equations } \\
\hline K & 1048.50 & 1100.00 & 1032.55 & 1000.07 & 1000.00 \\
\hline a & 0.197 & 0.163 & 0.400 & 0.163 & 0.400 \\
\hline$b$ & 14.15 & 16.47 & 30.00 & 15.45 & 20.04 \\
\hline C & 0.800 & 0.766 & 0.600 & 0.747 & 0.600 \\
\hline \multirow[t]{2}{*}{ RMSE } & 6.51 & 3.67 & 210.98 & 3.73 & 247.02 \\
\hline & \multicolumn{5}{|c|}{ Hybrid equations } \\
\hline K & 1053.87 & 1000.35 & 1000.00 & 1000.00 & 1000.00 \\
\hline a & 0.205 & 0.170 & 0.400 & 0.170 & 0.400 \\
\hline$b$ & 17.14 & 19.99 & 20.00 & 20.00 & 20.00 \\
\hline C & 0.800 & 0.735 & 0.600 & 0.735 & 0.600 \\
\hline RMSE & 9.49 & 7.52 & 250.80 & 7.00 & 250.81 \\
\hline
\end{tabular}

RMSE - Root Mean Square Error

$\mathrm{OF}_{2}$ : the $\mathrm{K}, \mathrm{a}, \mathrm{b}$ and c coefficients were $1,100.00,0.163,16.47$, and 0.766 , respectively. For the hybrid intensity-durationfrequency equation, the lowest RMSE value was obtained by applying $\mathrm{OF}_{4}$ : the $\mathrm{K}$, a, b and c coefficients were $1,000.00,0.170$, 20.00 , and 0.735 , respectively.

Equations 7 and 8 show the intensity-duration-frequency equations obtained from the adjustment of the conventional and hybrid series values (years 1982-2015), respectively, according to Eq. 1.

$$
\begin{aligned}
& I=\frac{1100 R P^{0.163}}{(t+16.47)^{0.766}} \\
& I=\frac{1000 R P^{0.170}}{(t+20.00)^{0.735}}
\end{aligned}
$$

The intensity-duration-frequency equations presented here provide additional information for future hydrological studies of Pelotas, RS state, Brazil, compared to previous ones: their maximum rainfall intensity values are valid for durations of 5 min, while those of the relationships presented by Goulart et al. (1992) were valid only for durations of $30 \mathrm{~min}$ or higher.

The intensity-duration-frequency equations should be periodically reviewed to include extreme events, since they are obtained from data samples over a period of $\mathrm{n}$ years; this process ensures a proper use of these relationships in hydraulic structure projects.

Since the final objective of this kind of study would be to model intense rainfalls of even shorter duration (Oliveira et al., 2005), it is important to identify the smallest rainfall intensity values used to obtain the intensity-duration-frequency equations: this would allow the generation of enough points to define intensity-duration-frequency equations which describe different return periods, and completely characterize them.

The intensity-duration-frequency equations relations presented here refer to the period of 1982-2015 (34 years) and include a series of updated data, whereas the relationships presented by Goulart et al. (1992) referred to an earlier and shorter time period (1961-1991: 31 years); additionally, it is important to consider the current rainfall characteristics associated with the hydroclimatological changes (Horikoshi \& Fisch, 2007).

Table 6 presents values of $\beta_{1}$ coefficient, Student's t-test, $\mathrm{t}\left(\beta_{1}\right)$, the probability $(\mathrm{p})$ of type I error and the correlation coefficient ( $r$ ) values, allowing a comparison of the maximum rainfall intensities obtained from the hybrid and conventional intensity-duration-frequency equations.

The maximum intensities obtained from the hybrid and conventional intensity-duration-frequency equations do not differ for all return periods: the values calculated from $t$ for the coefficient $\beta_{1}$ were lower than the critical value of $\mathrm{t}(0.05)$ (Table 6); hence, the $\mathrm{H}_{0}$ hypothesis can be accepted.

It is possible to use the appropriate probability distribution, which is adjusted to the data series. On the other hand, it is possible to use the empirical form to acquire new data when long historical series are available. Continuous revisions of the intensity-duration-frequency relationships are particularly needed once new pluviographic records are incorporated into previous historical series: they will include new extreme rainfall events.

In several studies (Silva et al., 2002; Oliveira et al., 2005; Garcia et al., 2011; Ghanmi et al., 2016), intensity-durationfrequency equations were obtained following a standardized methodology: (i) the maximum annual rainfall was calculated for each duration, based on historical data; (ii) a theoretical probability distribution was adjusted for each duration; (iii) each rainfall value was divided by its duration, obtaining the correspondent intensity; (iv) the resulting curves were used to reconstruct the intensity-duration-frequency relationships.

In the present study, instead, an hybrid intensityduration-frequency equation was calculated. Here, the values of maximum rainfall intensities for return periods of 2, 5, 10,20 , and 25 years were obtained by empirical frequency analysis (using the Weibull formulation), whereas those for return periods of 50 and 100 years were obtained from the conventional intensity-duration-frequency equation (using the probability distribution that best fitted the data series).

Goulart et al. (1992) studied the same municipality which was the focus of this investigation: the city of Pelotas, RS state, Brazil. They defined as intense rainfalls those ones that met minimum intensity values of $40,25,15,6.3,3.7$ and $2.3 \mathrm{~mm} \mathrm{~h}^{-1}$, respectively for rainfall durations of $30,60,120,360,720$ and 1440 min (years 1961-1991).

Table 6. Values of $\beta_{1}$ coefficient, Student's t-test, $t\left(\beta_{1}\right)$, the probability $(\mathrm{p})$ of type I error and the correlation coefficient (r), obtained by comparing the maximum rainfall intensities $\left(\mathrm{I}_{\max }\right)$ obtained from the hybrid and conventional intensityduration-frequency (IDF) equations for return periods (RP)

\begin{tabular}{|c|c|c|c|c|}
\hline $\begin{array}{c}\mathbf{R P} \\
\text { (years) }\end{array}$ & $\beta_{1}$ & $t\left(\beta_{1}\right)$ & $\mathbf{p}$ & $\mathbf{r}$ \\
\hline \multicolumn{5}{|c|}{ Conventional IDF Imax versus Hybrid Imax } \\
\hline 2 & 0.8971 & 0.11 & 0.46 & \multirow{7}{*}{0.9978} \\
\hline 5 & 0.9029 & 0.11 & 0.46 & \\
\hline 10 & 0.9073 & 0.10 & 0.46 & \\
\hline 20 & 0.9117 & 0.10 & 0.46 & \\
\hline 25 & 0.9131 & 0.10 & 0.46 & \\
\hline 50 & 0.9175 & 0.09 & 0.47 & \\
\hline 100 & 0.9220 & 0.08 & 0.47 & \\
\hline
\end{tabular}
of $2,5,10,20,25$ and 100 years 
In this study different values from those of Goulart et al. (1992) were obtained. In fact, were considered as intense rainfalls those that, for durations of $5,10,15,20,30,60,120$, 360,720 and $1440 \mathrm{~min}$, reached minimum rainfall values of 5 , $9,13,14,15,19,24,30,40$ and $53 \mathrm{~mm}$, respectively (these values include the maximum and minimum values of the series).

In terms of maximum rainfall intensities, this work considered as intense rainfalls those that, for durations of 5, 10, 15, 20, 30, $60,120,360,720$ and $1440 \mathrm{~min}$, met minimum intensity values of $60,54,52,42,30,19,12,5,3.33$ and $2.21 \mathrm{~mm} \mathrm{~h}^{-1}$, respectively (years 1982-2015).

\section{Conclusions}

1. Two equations obtained can characterize the intensity, duration and frequency of precipitations in the locality of Pelotas, RS state, Brazil, based on rainfall records, considering both the conventional methodology (empirical models) and a hybrid methodology (theoretical models).

2. The conventional and hybrid methodologies provided maximum rainfall intensity values for the durations and the pre-established return periods, avoiding any loss of information: no significant differences were found between the values obtained from the two methodologies.

3. The maximum rainfall intensity values associated with the durations and return periods can be determined through an empirical formulation, provided that the number of elements of the series is equal or greater than the established return period.

4. The objective function influences the choice of the parameters related to the intensity, duration and frequency equations; hence, it is important to estimate the maximum rainfall intensity values for the locality of interest.

\section{Literature Cited}

Back, A. J.; Hen, A.; Oliveira, J. L. R. Heavy rainfall equations for Santa Catarina, Brazil. Revista Brasileira Ciência do Solo, v.35, p.21272134, 2011. https://doi.org/10.1590/S0100-06832011000600027

Beskow, S.; Caldeira, T. L.; Mello, C. R. de; Faria, L. C.; Guedes, H. A. S. Multiparameter probability distributions for heavy rainfall modeling in extreme Southern Brazil. Journal of Hydrology, v.4, p.123-133, 2015. https://doi.org/10.1016/j.ejrh.2015.06.007

Blain, G. C.; Camargo, M. B. P. de. Probabilistic structure of an annual extreme rainfall series of a coastal area of the State of São Paulo, Brazil. Engenharia Agrícola, v.32, p.552-559, 2012. https://doi. org/10.1590/S0100-69162012000300014

Blain, G. C.; Meschiatti, M. C. Using multi-parameters distributions to assess the probability of occurrence of extreme rainfall data. Revista Brasileira de Engenharia Agrícola e Ambiental, v.18, p.307313, 2014. https://doi.org/10.1590/S1415-43662014000300010

Borga, M.; Vezzani, C.; Fontana, G. D. Regional rainfall depthduration-frequency equations for an Alpine Region. Natural Hazards, v.36, p.221-235, 2005. https://doi.org/10.1007/s11069004-4550-y

Damé, R. de C. F. Desagregação de precipitação diária para estimativa de curvas intensidade-duração-frequência. Porto Alegre: UFRGS, 2001. 131p. Tese Doutorado
Damé R. de C. F.; Teixeira-Gandra, C. F. A.; Guedes, H. A. S.; Silva, G. M. da; Silveira, S. C. R. da. Intensity-duration-frequency relationships: Stochastic modeling and disaggregation of daily rainfall in the lagoa Mirim watershed, Rio Grande do Sul, Brazil. Engenharia Agrícola, v.36, p.492-502, 2016. https:/doi. org/10.1590/1809-4430-Eng.Agric.v36n3p492-502/2016

Fechine Sobrinho, V.; Rodrigues, J. O.; Mendonça, L. A. R.; Andrade, E. M. de; Tavares, P. R. L. Desenvolvimento de equações intensidade-duração-frequência sem dados pluviográficos em regiões semiáridas. Revista Brasileira Engenharia Agrícola e Ambiental, v.18, p.727-734, 2014. https://doi.org/10.1590/S141543662014000700009

Ferreira, J. C.; Daniel, L. A.; Tomazela, M. Parâmetros para equações mensais de estimativas de precipitação de intensidade máxima para o estado de São Paulo: Fase I. Ciência e Agrotecnologia, v.29, p.1175-1187, 2005. https://doi.org/10.1590/S141370542005000600011

Garcia, S. S.; Amorim, R. S. S.; Couto, E. G.; Stopa, W. H. Determinação da equação intensidade-duração-frequência para três estações meteorológicas do Estado de Mato Grosso. Revista Brasileira de Engenharia Agrícola e Ambiental, v.15, p.575-581, 2011. https:// doi.org/10.1590/S1415-43662011000600006

Ghanmi, H.; Bargaoui, Z.; Mallet, C. Estimation of intensityduration-frequency relationships according to the property of scale invariance and regionalization analysis in a Mediterranean coastal area. Journal of Hydrology, v.541, p.38-49, 2016. https:// doi.org/10.1016/j.jhydrol.2016.07.002

Goulart, J.; Maestrini A. P.; Nebel, A. L. Relação intensidade-duraçãofrequência de chuvas em Pelotas, RS. Revista Brasileira de Meteorologia, v.7, p.543-552, 1992.

Horikoshi, A. S.; Fisch, G. Balanço hídrico atual e simulações para cenários climáticos futuros no Município de Taubaté, SP, Brasil. Revista Ambiente \& Água, v.2, p.33-46, 2007. https://doi. org/10.4136/ambi-agua.25

Kendall, M. G.; Stuart, A. The advanced theory of statistics. London: Charles Griffin \& Company Limited, 1967. 449p.

Kruel, I. B.; Meschiatti, M. C.; Blain, G. C.; Ávila, A. M. H. de. Climate trends in the municipality of Pelotas, state of Rio Grande do Sul, Brazil. Engenharia Agrícola, v.35, p.769-777, 2015. https://doi. org/10.1590/1809-4430-Eng.Agric.v35n4p769-777/2015

Martínez, M. C. A.; Marin, L. J. H.; Camargo, L. G. Z. Modelado del proceso de hidrotratamiento de diésel. Revista ION, v.25, p.7-14, 2012.

Mello, C. R. de; Viola, M. R. Mapeamento de chuvas intensas no estado de Minas Gerais. Revista Brasileira de Ciência do Solo, v.37, p.37-44, 2013. https://doi.org/10.1590/S0100-06832013000100004

Oliveira, L. F. C. de; Cortês, F. C.; Wehr, T. R.; Borges, L. B.; Sarmento, P. H. L.; Griebeler, N. P. Intensidade-duração-frequência de chuvas intensas para localidades no estado de Goiás e Distrito Federal. Pesquisa Agropecuária Tropical, v.35, p.13-18, 2005.

Pinheiro, A.; Graciano, R. L. G.; Severo, D. L. Tendência das séries temporais de precipitação da Região Sul do Brasil. Revista Brasileira de Meteorologia, v.28, p.281-290, 2013. https://doi. org/10.1590/S0102-77862013000300005

R Development Core Team. R: A language and environment for statistical computing. Vienna: R Foundation for Statistical Computing, 2011. 
Ramos, P. L.; Moala, F. A. A aplicação da distribuição exponencial geométrica estendida para modelagem de dados pluviométricos. Revista Brasileira de Meteorologia, v.29, p.613-620, 2014. https:// doi.org/10.1590/0102-778620130612

Sansigolo, C. A. Distribuições de extremos de precipitação diária, temperatura máxima e mínima e velocidade do vento em Piracicaba, SP (1917-2006). Revista Brasileira de Meteorologia, v.23, p.341-346, 2008. https://doi.org/10.1590/S0102-77862008000300009

Silva, D. D. de; Gomes Filho, R. R.; Pruski, F. F.; Pereira, S. B.; Novaes, L. F. de. Chuvas intensas no estado da Bahia. Revista Brasileira de Engenharia Agrícola e Ambiental, v.6, p.362-367, 2002. https:// doi.org/10.1590/S1415-43662002000200030

Silva, J. M. A.; Pruski, F. F.; Silva, D. D.; Cecílio, R. A. Metodologia para obtenção do hidrograma de escoamento superficial em encostas e canais. Parte I: Desenvolvimento e avaliação. Engenharia Agrícola, v.26, p.695-703, 2006. https://doi.org/10.1590/S0100-69162006000300005

Silva, S. D. da; Streck, N. A. Tendências das séries históricas do índice de calor no município de Santa Maria - RS. Ciência Rural, v.44, p.1360-1366, 2014. https://doi.org/10.1590/0103-8478cr20131345
Soccol, O. J.; Cardoso, C. O.; Miquelluti, D. J. Análise da precipitação mensal provável para o município de Lages, SC. Revista Brasileira de Engenharia Agrícola e Ambiental, v.14, p.569-574, 2010. https://doi.org/10.1590/S1415-43662010000600001

Souza, J. L. M. de; Jerszurki, D.; Damazio, E. C. Relações funcionais entre precipitação provável e média em regiões e climas brasileiros. Pesquisa Agropecuária Brasileira, v.48, p.693-702, 2013. https:// doi.org/10.1590/S0100-204X2013000700001

Souza, R. O. R. de M.; Scaramussa, P. H. M.; Amaral, M. A. C. M. do; Pereira Neto, J. A.; Pantoja, A. V.; Sadeck, L. W. R. Equações de chuvas intensas para o estado do Pará. Revista Brasileira de Engenharia Agrícola e Ambiental, v.16, p.999-1005, 2012. https:// doi.org/10.1590/S1415-43662012000900011

Teixeira, C. F. A.; Damé, R. de C. F.; Rosskoff, J. L. C. Intensityduration-frequency ratios obtained from annual records and partial duration records in the locality of Pelotas-RS, Brazil. Engenharia Agrícola, v.31, p.687-694, 2011. https://doi. org/10.1590/S0100-69162011000400007 